\title{
ANALISIS MAKNA KOTOWAZA YANG TERKAIT DENGAN KANII MUSIM DAN RELEVANSINYA DENGAN KEBUDAYAAN JEPANG
}

\author{
Mia Kharina \\ Drs. H. Sudjianto, M.Hum.', \\ Dra. Neneng Sutjiati, M.Hum. ${ }^{2}$ \\ Departemen Pendidikan Bahasa Jepang \\ Fakultas Pendidikan Bahasa dan Sastra \\ Universitas Pendidikan Indonesia \\ mia.kharina@gmail.com
}

\begin{abstract}
Abstrak
Kebudayaan adalah suatu cara hidup yang berkembang dan dimiliki bersama oleh sekelompok orang dan diwariskan dari generasi ke generasi. Evolusi kebudayaan berhubungan erat dengan kondisi lingkungan. Maka dari itu, budaya di setiap negara berbeda-beda berdasarkan lingkungannya. Salah satu faktor yang terlihat jelas adalah iklim atau musim di sebuah negara. Adanya perubahan musim mempengaruhi kebudayaan yang berkembang di masyarakatnya. Kemudian, salah satu unsur dari kebudayaan terdapat bahasa. Bahasa tidak terbatas dengan interaksi sehari-hari, tetapi banyak sarana sastra yang dapat dijadikan objek pembelajaran. salah satunya, peribahasa yang merupakan ajaran berdasarkan pola pikir orang Jepang dari zaman dahulu. Orang Jepang sering menggunakan peribahasa dalam mengungkapkan atau menggambarkan suatu keadaan dalam kehidupan sehari-hari. Namun, pada kenyataannya sebagian pembelajar bahasa Jepang tidak memahami makna dari peribahasa bahasa Jepang. Penelitian ini bertujuan untuk mencari tahu makna peribahasa dan relevansinya terhadap kebudayaan Jepang. Penulis membatasi peribahasa yang digunakan hanya peribahasa yang berkaitan dengan kanji musim (haru, natsu, aki, fuyu). Oleh karena itu penulis merumuskan masalah penelitian sebagai berikut : 1) apa sajakah peribahasa Jepang yang terkait dengan kanji musim (haru, natsu, aki, fuyu), 2) apa makna peribahasa tersebut dalam bahasa Indonesia, 3) adakah relevansi kebudayaan yang tersirat dalam peribahasa Jepang yang terkait dengan kanji musim (haru, natsu, aki, fuyu). Metode yang digunakan pada penelitian ini adalah metode penelitian deskriptif dan kualitatif. Hasil dari penelitian ini, ditemukan 20 peribahasa yang berkaitan dengan kanji musim dan 12 diantaranya memiliki relevansi dengan kebudayaan Jepang berdasarkan musim. Dengan begitu dapat ditarik kesimpulan adanya keterkaitan antara keadaan lingkungan atau kebudayaan yang berdasarkan musim mempengaruhi pembentukan peribahasa di sebuah negara.
\end{abstract}

Kata kunci: peribahasa, makna, kebudayaan, musim

\footnotetext{
${ }^{1}$ Penanggung Jawab 1

${ }^{2}$ Penanggun gJawab 2
} 


\title{
Analysis The Meaning of Kotowaza Associated with Kanji Season and Its Relevance to Japanese Culture
}

\author{
Mia Kharina \\ Drs. H. Sudjianto, M.Hum.', \\ Dra. Neneng Sutjiati, M.Hum. ${ }^{2}$ \\ Departemen Pendidikan Bahasa Jepang \\ Fakultas Pendidikan Bahasa dan Sastra \\ Universitas Pendidikan Indonesia \\ mia.kharina@gmail.com
}

\begin{abstract}
s
Culture is the way of life that developed and shared by a community that are passed from generation to generation. Cultural evolution is closely related with enviromental conditions. Therefore, the culture in each country is different based on environment. One of the obious factor is the climate or season in a country. The changing seasons affect the cultures that developed in the society. Then, one of the elements of culture are language. Language is not the daily interactions only, but many literary device that can be used as learning objects. One of them is proverb that teaching based on the mindset of Japanese people from ancient times. Japanese people often use proverbs to express or describe a situation in daily life. However, in fact most of Japanese language learners didn't understand the meaning of Japanese proverbs. This research aims to find out the meaning of proverbs and relevance to the Japanese culture. Authors restrict to use proverbs which is related to kanji season (haru, natsu, aki, fuyu). Therefore, authors formulate the research problems as follow : 1) what are the Japanese proverbs which is associated with kanji season (haru, natsu, aki, fuyu), 2) what are the meaning of these proverbs in Indonesian, 3 ) is there any relevance of culture implicit in Japanese proverbs related kanji season (haru, natsu, aki, fuyu). The method used in this research is descriptive and qualitative research method. The result of this research, it was found 20 proverbs related to kanji season (haru, natsu, aki, fuyu) and 12 of them have relevance to the Japanese culture based on season. thus, it can be concluded there is a correlation between the state of environment or culture that is based on the proverbs season affect formation in a country.
\end{abstract}

Keywords : proverb, meaning, culture, season

${ }^{1}$ Supervisor 1

${ }^{2}$ Supervisor 2 


\section{A. PENDAHULUAN}

Kebudayaan adalah suatu cara hidup yang berkembang dan dimiliki bersama oleh sekelompok orang dan diwariskan dari generasi ke generasi. Cateora (dalam Sulasman 2013, hlm. 38) menyatakan berdasarkan wujudnya tersebut budaya memiliki beberapa elemen atau komponen sebagai berikut : kebudayaan materiil, kebudayaan nonmateriil, lembaga sosial, sistem kepercayaan, estetika, dan bahasa. Sulasman (2013, hlm. 39) menyatakan isi unsur kebudayaan akan berbeda antara kebudayaan satu dan kebudayaan lainnya. Hal ini dipengaruhi oleh berbagai faktor, diantaranya faktor geografis khususnya iklim atau musim di sebuah negara. Adanya perubahan musim mempengaruhi kebudayaan yang berkembang di masyarakatnya. Tumanggor $(2014, \mathrm{hlm}$. 20) menyatakan antara manusia dan kebudayaan terjalin hubungan yang sangat erat, karena menjadi manusia tidak lain adalah merupakan bagian dari hasil kebudayaan itu sendiri. Hampir semua tindakan manusia merupakan produk kebudayaan. Budaya bukanlah suatu yang statis dan kaku, tetapi senantiasa berubah sesuai perubahan sosial yang ada sebab kebudayaan berfungsi mempermudah kehidupan manusia.. Kemudian salah satu unsur kebudayaan itu salah satunya adalah bahasa. Cateora (dalam Sulasman 2013, hlm 39) menyatakan bahasa merupakan alat pengantar dalam berkomunikasi. Setiap wilayah, bagian, dan negara memiliki perbedaan bahasa yang sangat kompleks. Dalam ilmu komunikasi, bahasa merupakan komponen yang sulit dipahami. Bahasa memiliki sifat unik dan kompleks yang hanya dapat dimengerti oleh pengguna bahasa tersebut. Sudjianto (2007, hlm. 5) menyatakan pembelajaran bahasa asing tidak hanya mencakup bahasa yang digunakan sehari-hari. Ruang lingkup dalam pembelajaran bahasa bisa bermacam-macam, misalnya sastra, ekonomi, budaya, sosial, dan sebagainya. Misalnya, peribahasa yang merupakan ajaran berdasarkan pola pikir orang Jepang dari zaman dahulu. Orang Jepang sering menggunakan peribahasa dalam mengungkapkan atau menggambarkan suatu keadaan dalam kehidupan sehari-hari. Peribahasa dalam Kamus Besar Bahasa Jepang (1986, hlm. 960) diartikan sebagai rangkaian kata atau ungkapan pendek yang berisikan sarkasme, sindiran, ucapan tidak langsung, nasihat, peringatan, dan sebagainya yang disampaikan dari zaman dahulu. Dilihat dari makna peribahasa Jepang yang terdapat pada Kamus Besar Bahasa Jepang, sedikitnya terlihat hubungan antara peribahasa Jepang dengan kebudayaan Jepang. Penelitian ini bemaksud untuk mencari tahu makna dan hubungan yang ada antara peribahasa Jepang dan kebudayaan Jepang. Tujuan penelitian ini adalah untuk mencari tahu makna yang terkandung dalam sebuah peribahasa Jepang yang terkait kanji musim. Tujuan detailnya seperti yang disebutkan dibawah ini :

1. Untuk mengetahui apa saja peribahasa Jepang yang terkait dengan kanji musim 「春夏秋冬」(Haru, Natsu, Aki, Fuyu).

2. Mengetahui makna yang dimiliki oleh peribahasa Jepang yang terkait dengan kanji musim 「春夏秋冬」( Haru, Natsu, Aki, Fuyu). 
3. Mengetahui relevansi budaya yang tersirat dalam peribahasa jepang yang terkait dengan kanji musim 「春夏秋冬」(Haru, Natsu, Aki, Fuyu).

\section{B. METODE PENELITIAN}

Sutedi, (2011, hlm. 58) mengemukakan penelitian deskriptif merupakan penelitian yang dilakukan untuk menggambarkan, menjabarkan suatu fenomena yang terjadi saat ini dengan menggunakan prosedur ilmiah untuk menjawab masalah secara aktual. Kemudian Newton Bogdan dan Taylor (dalam Moleong 2007, hlm. 4) penelitian kualitatif adalah prosedur penelitian yang menghasilkan data deskriptif berupa kata-kata tertulis atau lisan dari orang-orang dan perilaku yang dapat diamati. Sesuai dengan sifat dari metode deskriptif dan metode kualitatif, metode ini dipilih untuk memecahkan masalah terhadap suatu objek dengan cara mengumpulkan data, menyusun, dan mengkasifikasikannya serta menganalisis data yang ada kemudian diuraikan secara apa adanya dalam penelitian ini. Tahaptahap analisis data yang akan dilakukan yaitu sebagai berikut:

1. Mengumpulkan peribahasa bahasa Jepang yang terkait dengan kanji musim.

2. Mengidentifikasi, mengkaji serta mengartikan setiap peribahasa bahasa Jepang yang terkait dengan kanji musim yang telah dikumpulkan.

3. Menghubungkan adanya keterkaitan anatar peribahasa bahasa Jepang yang terkait dengan kanji musim dengan kebudayaan yang ada di masyarakat Jepang.

4. Membuat kesimpulan dari hasil yang diperoleh setelah semua proses pengolahan data selesai dilakukan.

\section{HASIL DAN PEMBAHASAN}

Dari penelitian yang telah dilakukan didapat peribahasa yang terkait dengan kanji musim adalah sebagai berikut :

1. 秋茄子嫁に食わすな (aki nasubi yome ni kuwasu na) memiliki makna merupakan sebuah ucapan seorang ibu mertua yang tidak ingin membagi menantu perempuannya makan terong musim gugur. Kemudian di satu sisi juga memiliki makna yang berarti sebuah saran seorang ibu mertua yang tidak ingin menantu permpuannya tidak memiliki anak. Peribahasa ini memiliki relevansi dengan kegiatan atau festival Minori no Aki 「実りの秋」 yang artinya adalah panen musim gugur. Pada musim ini banyak sekali sayur-mayur dan buahbuahan yang dipanen. Karena musim gugur merupakan musim dimana buah-buahan dan sayur mayur terasa nikmat. Tetapi sebenarnya makna peribahasa ini lebih kepada asal-usul yang berada di Jepang. Pemikiran orang Jepang yang didasari oleh jenis terong musim gugur yang jumlah rumpun yang sedikit niscaya jika seorang menantu perempuan diberi makan terong musim gugur maka tidak dapat memiliki anak.

2. 秋の雨が降れば猫の顔が三尺になる (aki no ame ga fureba neko no kao ga sanjaku ni naru) memiliki makna dimana menggambarkan seekor kucing yang peka terhadap dingin merasakan perasaan bahagia ketika hujan turun pada musim gugur. Peribahasa ini memiliki 
relevansi yang lebih condong kepada pola pikir masyarakat orang Jepang yang menyayangi binatang terutama kucing. Hujan pada musim gugur membawa tekanan udara rendah dari selatan sehingga membuat hari menjadi hangat. Kucing yang dianggap peka terhadap dingin akan merasa senang jika hujan turun di musim gugur.

3. 秋の扇 (aki no ougi) memiliki makna dimana seorang perempuan yang kehilangan cinta seorang laki-laki. Disatu sisi bisa diartikan melupakan kebaikan yang telah dilakukan sang kipas selama musim panas. Hal ini sama dengan sifat manusia yang bisa melupakan kebaikan seseorang. Peribahasa ini memiliki relevansi dengan kebiasaan ochuugen 「お中元」 yang artinya hadiah pertengahan tahun yang biasanya dilakukan pada pertengahan tahun (tepatnya bulan Juli, musim panas). Hal ini dilakukan agar tidak melupakan kebaikan yang pernah orang lain berikan pada kita.

4. 秋の日と娘の子はくれぬようでくれる (aki no hi to musume no ko ha kurenu youni kureru) memiliki makna perumpamaan antara matahari di musim gugur dan anak perempuan. Peribahasa ini memiliki relevansi dengan shuubun no hi yang artinya adalah hari ekuinoks atau puncak musim gugur. Dimana panjang waktu siang dan malam sama tidak ada bedanya. Jika sudah melewati puncak musim gugur, waktu pada siang hari akan menjadi lebih pendek. Pemikiran orang Jepang yang menggantungkan pada pengucapan kata 'kureru' pun berdasarkan dari puncak musim gugur tersebut.

5. 秋の日は釣瓶落とし (aki no hi ha tsurube otoshi) memiliki makna dimana hari musim gugur bagaikan menjatuhkan timba air pada sumur. Peribahasa ini memiliki relvansi dengan shuubun no hi yang artinya hari ekuinoks atau puncak musim gugur. Dimana panjang waktu siang dan malam sama tidak ada bedanya. Jika sudah melewati puncak musim gugur, waktu pada siang hari akan menjadi lebih pendek. Orang Jepang selalu memperhatikan sesuatu sangat mendetail, dengan adanya pemikiran dimana menyamakan matahari pada musim gugur dan timba air artinya ada pengaruh lingkungan dan juga tanggapan manusia terhadap perubahan alam sekitar, yang dimana keduanya merupakan faktor pembentuk kebudayaan.

6. いただくものは夏も小袖・貪う物は夏も小袖(itadaku mono ha natsu no kosode - morau mono ha natsu no kosode) memiliki makna dimana seseorang yang tamak akan menerima apapun yang diberikan orang lain. Meskipun ia mendapatkan benda yang tidak ada gunanya sama sekali. Peribahasa ini memiliki relevansi yang lebih condong kepada pola pikir dimana yang telah di paparkan pada bab sebelumnya, kebudayaan adalah cara berpikir, cara merasa, cara meyakini, dan menganggap.

7. 一葉落ちて天下の秋を知る(ichyou ochite tenka no aki wo shiru) memiliki makna seseorang yang dapat memprediksi datangnya sebuah pertiwa dari pertanda yang kecil. Peribahasa ini memiliki relevansi dengan pola pikir manusia Jepang. Peribahasa ini menggambarkan sebuah peristiwa yang terlintas pada musim gugur yang dijadikan 
sebuah perumpamaan untuk memprediksi sebuah peristiwa. Pola pikir orang Jepang yang cepat tanggap terhadap suatu peristiwa bisa dianggap sebagai pengetahuan yang dimiliki oleh orang Jepang.

8. 男心と秋の空・女心と秋の空 (otoko gokoro to aki no sora ・ onna gokoro to aki no sora) memiliki makna perasaan seseorang yang tidak bisa ditebak dan mudah berubah-ubah bagaikan langit musim gugur. Baik perempuan atau laki-laki dapat digambarkan dengan peribahasa ini. Peribahasa ini memiliki relevansi dengan pola pikir manusia Jepang. Peribahasa ini merupakan sebuah penggambaran bahwa hari seseorang tidak mudah ditebak dan gampang berubah-ubah bagaikan langit pada musim gugur.

9. 夏炉冬扇 (karou tousen) memiliki makna benda yang tidak memiliki fungsi atau sama sekali tidak berguna. Peribahasa ini memiliki relevansi yang lebih condong kepada pola pikir orang Jepang yang melihat fungsi benda tersebut. Lingkungan terutama musim dan manusia dalam sebuah negara tertentu merupakan faktor terbesar teciptanya sebuah kebudayaan.

10. 春宵一刻值千金 (shunshou ikkoku atai senkin) memiliki makna dimana malam hari yang terasa sangat nyaman pada musim semi. Peribahasa ini memiliki relevansi dengan hanami atau melihat bunga sakura pada musim semi. Karena malam pada musim semi sangatlah nyaman dan cantik maka lahirlah kebudayaan yozakura「夜桜」 yang artinya sakura malam hari. Ini merupakan perkembangan dari hanami

「花見」 yang biasa dilakukan oleh orang Jepang hanya saja melihat bunga sakura ini dilaksanakan pada malam hari dimana sinar terang rembulan menyinari dan bunga sakura yang berguguran membuat malam semakin nyaman dan cantik. Peribahasa ini sampai sekarang pun masih digunakan untuk menggambarkan musim semi yang tidak ternilai cantiknya.

11. 春眠暁覚えず (shunmin akatsuki oboezu) memiliki makna seseorang yang tertidur lelap sehingga tidak menyadari bahwa matahari telah terbit dikarenakan malam hari pada musim semi yang pendek dan nyaman. Peribahasa ini memiliki relevansi dengan shunbun no hi yang artinya hari ekuinoks atau puncak musim semi. Merupakan salah satu penggambaran puncak musim semi atau hari ekuinoks musim semi yaitu hari dimana panjang waktu siang dan malam sama tidak ada bedanya. Jika sudah melewati puncak musim semi, waktu pada siang hari akan menjadi panjang. Sehingga orang Jepang merasa waktu istirahat mereka pada musim semi semakin berkurang.

12. 冬至十日経てば阿呆でも知る (touji tooka tateba ahou demo shiru) memiliki makna dimana orang bodoh sekali pun memahami bila matahari semakin lama tampak setelah melewati 10 hari setelah puncak musim dingin. Peribahasa ini memiliki relevansi dengan touji atau puncak musim dingin. Adanya isyarat pada peribahasa ini merupakan sebuah peringatan berdasarkan pengalaman orang Jepang terhadap musim dingin. Peribahasa ini menyatakan hal yang jelas akan terjadi setelah melewati puncak musim dingin. 
13. 冬至冬中冬始め (touji fuyu naka fuyu hajime) memiliki makna puncak musim dingin merupakan musim dingin yang sebenarnya. Peribahasa ini memiliki relevansi dengan touji atau puncak musim dingin. Puncak musim dingin bertepatan dengan pertengahan musim dingin yang dimana setelah melewati puncak musim dingin malam hari semakin lama dan angin malam akan menjadi lebih dingin daripada biasanya. Peribahasa ini pun berasal dari pemikiran dan pengalaman orang Jepang setelah melewati puncak musim dingin.

14. 飛んで火に入る夏の虫 (tonde hi ni iru natsu no mushi) memiliki makna seseorang yang membawa dirinya sendiri jatuh kedalam kemalangan atau bencana. Peribahasa ini memiliki relevansi yang lebih condong ke pola pikir manusia Jepang. Peribahasa ini menggambarkan keadaan lingkungan pada musim panas yang melihat serangga musim panas yang mendekati api atau lampu di musim panas akan membuatnya mati terbakar.

15. 夏の風は大も食わぬ (natsu no kaze ha inu mo kuwanu) memiliki makna melakukan hal yang sangat bodoh. Peribahasa ini memiliki relevansi yang lebih condong ke pola pikir manusia Jepang. Ada pepatah orang Jepang yang mengatakan 'baka ha kaze hikanu' yang artinya orang bodoh pun tidak akan sakit flu (masuk angin). Peribahasa ini menggambarkan kebodohan yang fatal jika melewatkan musim panas dengan sakit flu.

16. 夏の虫水を笑う (natsu no mushi koori wo warau) memiliki makna seseorang yang hanya memiliki pengetahuan serta pengalaman yang sedikit. Peribahasa ini memiliki relevansi dengan dokusho shuukan yang artinya pekan membaca. Ini merupakan kebiasaan yang dibiasakan oleh orang Jepang untuk banyak membaca buku dan menambah wawasan.

17. 春の晚飯後三里 (haru no banmeshi ato sanri) memiliki makna dimana hari pada musim semi terasa sangat lama. Peribahasa ini memiliki relevansi dengan shunbun no hi yang artinya hari ekuinoks atau puncak musim semi. Hari dimana panjang waktu siang dan malam sama tidak ada bedanya. Jika sudah melewati puncak musim semi, waktu pada siang hari akan menjadi panjang.

18. 一人娘と春の日はくれそうでくれぬ (hitori musume to haru no hi ha kuresou de kurenu) memiliki makna perumpamaan antara matahari di musim semi dan anak perempuan. Peribahasa ini memiliki relevansi dengan shunbun no hi yang artinya hari ekuinoks atau puncak musim semi. Hari dimana panjang waktu siang dan malam sama tidak ada bedanya. Pemikiran peribahasa ini menuju kepada kebudayaan pada musim semi dimana setelah hari ekuinoks, siang hari akan menjadi lebih panjang di banding malam hari.

19. 冬来たりなば春遠からじ (fuyu kitarinaba haru tookaraji) memiliki makna walaupun sekarang, terasa pahit dan penuh ketidakbahagiaan, jika dapat bertahan melewati semuanya, maka disitulah akan menunggu prospek harapan yang cerah. Peribahasa ini memiliki relevansi dengan touji (puncak musim dingin) dan risshun (awal 
musim semi) dimana kedua hal ini terjadi pada musim dingin. Setelah melewati puncak musim dingin maka akan datang awal musim semi yang hangat menyambut.

20. 物言えば唇寒し秋の風 (mono ieba kuchibiru samushi aki no kaze) memiliki makna seseorang yang merasa bahagia setelah mengumpat orang lain. Peribahas ini memiliki relevansi dengan pola pikir manusia Jepang. Peribahasa ini merupakan perumpamaan yang menggunakan kiasan kata "angin musim gugur" dimana suhu hembusan angin pada musim gugur akan semakin merendah dan menjadi dingin seperti saat kita mengumpat orang lain.

\section{KESIMPULAN}

Dari hasil yang diperoleh dapat disimpulkan beberapa hal seperti berikut :

1. Peribahasa Jepang yang terkait dengan kanji musim terdapat 20 peribahasa.

2. Dari 20 peribahasa Jepang yang terkait dengan kanji musim terdapat 12 peribahasa yang terdapat relevansinya dengan kebudayaan yang berdasarkan musim.

3. Peribahasa Jepang yang tekait dengan musim tidak terbatas hanya untuk mengiaskan keadaan alam saja tetapi juga mengiaskan suatu kejadian atau sebuah nasehat yang tersirat di dalamnya.

4. Adanya keterkaitan antara keadaan lingkungan atau kebudayaan yang berdasarkan musim mempengaruhi pembentukan peribahasa.

\section{E. REFERENSI}

Johannes Moleong, L. (2007) Metodologi Penelitian Kualitatif. Bandung : PT. Remaja Rosdakarya.

Sudjianto. (2007) Bahasa Jepang dalam Konteks Sosial dan Kebudayaannya. Bandung: UPI PRESS diambil dari : http://file.upi.edu/Direktori/FPBS/JUR._PEND._BAHASA_JEPA NG/195906051985031-

SUDJIANTO/7._Buku_Sosiolinguistik.pdf. (diakses tanggal 14 September 2014).

Sugiyono. (2012) Metode Penelitian Kuantitatif Kualitatif dan R\&D. Bandung : Alfabeta.

Sulasman., \& Gumilar, S. (2013) Teori-teori Kebudayaan dari Teori hingga Aplikasi. Bandung: Pustaka Setia.

Sutedi, D. (2011b) Penelitian Pendidikan Bahasa Jepang. Bandung : Humaniora.

Tumanggor, R., dkk. (2014) Ilmu Sosial dan Budaya Dasar. Jakarta : Kencana. 


\title{
日本文化と関係がある季節を表すことわざの意味の 分析
}

\section{Mia Kharina \\ Drs. H. Sudjianto, M.Hum.', \\ Dra. Neneng Sutjiati, M.Hum. ${ }^{2}$}

\author{
インドネシア教育大学 \\ 言語文芸教育学部 \\ 日本語教育学科 \\ mia.kharina@gmail.com
}

\begin{abstract}
要旨
文化というのは生活の中に発展し、社会も強調し合い、世代に 残された物である。文化の進化と環境は強く関係があった。従って、 夫々の国の文化は環境によって、異なることが多い。気候あるいは 季節はその一つの明らかの要素である。季節の移ろいは国に発展 した文化を影響した。さらに、言語は文化の要素の一つである。 言語と言うのは日常会話だけでなく、文学や彥なども勉強に成れる と思われる。例えば、ことわざというのは日本人の知恵や日本人の 生活経験から作られた物である。日本人は日常生活を表現寸る時に 時々ことわざを利用した。従来、彥の意味は、日本語学習者には あまり知られてない。本研究の狙いは季節を表すことわざの意味を 探り、日本の文化にどんな関係があるかを探りたい。本研究に 使われたことわざは季節を表すことわざ（春、夏、秋、冬）に 限られた。従って、本研究の疑問は以下のようである。1) 季節を 表寸彥から形成された日本の彥は何か、2) 季節を表寸浐意味は何か、 3) 季節を表す浐と日本文化はどんな関係があるか。研究問題を解決 するために、本研究で記述法と定性分析を使用寸る。結果から、

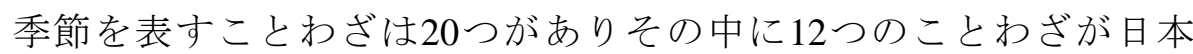
文化に関係があった。そのため、本研究の結論は、ことわざはその 国の文化と気候に関して強く影響されたということが分かってきた。

キーワード : ことわざ、意味、文化、季節
\end{abstract}

$1_{\text {責任者 } 1}$

2 責任者 2 


\section{A. はじめに}

文化というのは生活の中に発展し、社会も強調し合い、世代に 残された物である。Cateora (dalam Sulasman 2013, hlm. 38) は「文化は 形によって、文化の物質、文化の非物質、社会の組織、信仰、芸術、 言語の 6 つの要素があった。」と述べている。Sulasman $(2013$, hlm. 39)によると、「文化の要素は国々に発展した文化が異なった。この 事項は様々な要因に影響され、地形の要因はその一つ、特に国の気候 あるいは季節である。」と述べている。季節の移ろいは国に発展した 文化を影響した。Tumanggor (2014, hlm. 20) は「人間と文化は強く 関係があり、そのため人間はすでにその文化自身であろう。」 と説明した。文化は大体人間の行動から出来ていた。文化は静的と 窮屈ではないが、社交に流されていき、文化は人間の生活を易しく する役目がある訳であった。そして、言語は文化の要素の一つである。

Cateora (dalam Sulasman 2013, hlm. 39) によると、「言語は コミュニケーションの媒介語である。」と述べている。地方や部分 など及び国は複雑な言語の違いがあった。通信学科の中に、言語は 一番分かりにくい部分と思われる。言語の特質は特異と複雑でその 言語を利用する人だけが分かっていると考えられる。Sudjianto (2007, hlm. 5) は「外国語の学習と言うのは日常会話だけではない。」と説明 した。言語学習の範囲は様々であり、例えば文学や文化などである。 言語は日常会話だけでなく、多数文学手段が学習対象に成れると 考えられる。例えば、ことわざである。ことわざというのは日本人の 知恵や日本人の生活経験から作られた物である。日本人は日常生活を 表現する時に時々ことわざを利用した。国語辞典 $(1986, \mathrm{hlm}$. 960) に よると、「ことわざは昔から世間に広く言い習わされてきた教順や 風刺など含んだ短句。」と説明した。国語辞典にことわざの意味から 見ると、ことわざと日本文化は少し関係があった。ことわざも日本人 
の知恵や季節の変化などがあり、季節を表す諺はどんな意味と日本 文化とどんな関係があるかを探りたい。本研究の主な目的は「季節を 表す彥の意味はどんな意味を持ってるかを探っていく」ということで ある。より細かい目標としては以下のようである。

1．季節を表す彥から形成された日本の彥を探る。

2. 季節を表す彥意味を探っていく。

3．季節を表す彥と日本文化はどんな関係があるかを探る。

\section{B. 研究の方法}

本研究では、記述法を用いる。Sutedi (2011, hlm. 20) によると、 「記述研究は本格的である現象と状態を写寸研究である」と述べて いる。Newton Bogdan と Taylor (dalam Moelong 2007, hlm. 4) 「質的は デスクリプトのデータ、本文と口宣や観察された行儀などを到達した 方法である。」と説明した。記述法と質的の性質が説明したとおり、 本研究に使われた方法であり、本研究のデータを集める、類別し、 調査し、そしてそのまま説明した。研究の手順としては以下のようで ある。

1．季節を表すことわざを集めている。

2. 集めた季節を表すことわざを見分けり、調查し、解釈する。

3. 集めた季節を表すことわざと季節による日本文化の関係を明らか にする。

4. 本研究のデータ「集めた季節を表すことわざ」を加工し、結論を 作る。

\section{C. 分析の結果}

本研究に基づき、季節を表すことわざは以下のようである。

1.「秋茄子嫁に食わすな」というのは秋口のな寸は味がいいから嫁 には食わせたくない、という姑の意地悪である。一方、秋のなす は体を冷やして毒になるから大事な嫁には食わせないほうがいい と嫁を案じる言葉と思われる。このことわざは実りの秋と関係が あり、実りの秋というのは秋の収穫ということである。この季節 
に多数野菜や果物などを収穫された。したがって、秋の野菜や 果物などが美味しくなる季節と言われる。実際このことわざの 意味は、日本にある伝説を指す。秋の茄子は種類が少ないので、 嫁に食わせたら子供が出来ないと言われた。

2.「秋の雨が降れば猫の顔が三尺になる」というのは秋になると肌 寒い日が続くが、雨が降ると南方からの 低気圧のせいで暖かい。 そこで、寒がりの猫が三尺（役九十 センチメートル）も顔を長く して喜ぶということである。日本人が猫が大好きで、この ことわざは日本人の考え方と関係があった。秋の雨が降ると南方 からの低気圧のせいで暖かくなる。寒がりの猫が秋の雨が降れば 喜ぶということである。

3.「秋の扇」というのは不要のなった秋の扇に託して、男性の愛が 失った女性のたとえていうことである。一方、夏の間大事に 使われた扇も、秋が来ると顧みられなくなるという意味を持って いる。これも人間と同じような、他人の良さが忘れるという意味 である。このことわざはお中元と関係があり、お中元というのは 年の間中にある文化で、親戚や友達にプレゼントをあげるという ことである。他人の良さを忘れずにお中元の文化が生まれてきた。

4.「秋の日と娘の子はくれ妙でくれると」いうのは秋の日と娘 の子のたとえていうものである。このことわざは秋分の日と関係 があった。秋分の日は昼と夜の時間が大体同じになる日である。 秋分の日の数日後に、昼の時間が短くなった。日本人の考え方、

「暮れる」と「くれる」を与えたものである。

5.「秋の日は釣瓶落とし」というのは井戸の中へ釣瓶が垂直に速く 落ちるように秋の日は急に暮れるということである。この ことわざは秋分の日に関係があった。秋分の日は昼と夜の時間が 大体同じになる日である。秋分の日の数日に、昼の時間が短く なった。日本人は精密な人と言われており、秋の日と井戸の釣瓶 
のことを例えて言うものである。そのため、文化の要素を作るの は自然の変わりと人の意見も含めているということである。

6.「いただくものは夏も小袖・貪う物は夏も小袖」というのは どんなものでももらうということで、ひどく欲の深いことの たとえである。例え不要な物が、もらうものなら何でも構わない という意味にもいう。このことわざは日本人の考え方と関係が あった。文化というのは考え方や進行仕方などを表すことである。

7.「一葉落ちて天下の秋を知る」というのは小さな兆しを見て、 やがってやってくる出来事を察知することである。このことわざ は日本人の考え方と関係があった。このことわざは秋のにある 出来事を察知したもので、やってくることを例えていうもので ある。日本人はとある出来事に反応が早く、日本の知恵でもある と思われる。

8.「男心と秋の空・女心と秋の空」というのは秋の天候は変わり やすいものだが、人の心も同じように変わりやすく移り気だと いうことである。このことわざは場合によって、男と女も 使えられるこのことわざは日本人の考え方と関係があった。この ことわざは、秋の空と同じようで人に心は変わりやすく、簡単に 当たれらないと表している。

9.「夏炉冬扇」というのは時期外れで何の役にも立たないものの たとえである。このことわざは日本人の考え方と関係があり、物 の機能あるいは役目のことを考え、日本人の知恵である。文化の 要素は大体自然特に季節とその国に暮らした人間である。

10.「春宵一刻值千金」というのは春の夜の気持ちよさをいう言葉 ことである。このことわざは花見と関係があった。春の夜は非常 に機構で、気持ちい夜ですから、夜桜の文化が生まれてきた。 花見と同じようなことが夜桜というのは夜の眺めで、桜を見に行 くということである。このことわざも春のよさを表すときに いまだに使われている。 
11.「春眠暁覚えず」というのは春の夜は短いうえに気候が快適で、 夜明けも知らずに気持ちよく眠り込んでしまうことである。この ことわざは、春分の日と関係があった。春分の日は昼と夜の時間 が大体同じになる日である。春分の日の数日後には、昼の時間が 長くなった。従って、日本人は夜に休みの時間が少なくなったと 思わられる。

12.「冬至十日経てば阿呆でも知る」というのは冬至から十日も たてば、めっきりと日が長くなるので、どんな愚か者でも 気がつくということである。このことわざは冬至と関係があった。 このことわざに冬に対しての経験によって、警告が隠されている。 このことわざは、冬至を通過し、矢賀ってやってくる出来事を 警告したことである。

13.「冬至冬中冬始め」というのは冬至のころは、実際の冬の寒さは それ以後に始まるものだということである。このことわざは冬至 と関係があった。冬至は冬の中にあり、冬至から数日を通れば冬 の本当に寒さを知るということである。このことわざも日本人が 冬に経験した出来事から作られたものである。

14.「飛んで火に入る夏の虫」というのは自ら進んで災いの中に身を 投じるたとえである。このことおざは日本人の考え方と関係が あった。このことわざ、夏の間に生きる夏の虫は火や囲炉裏に 寄って、火に飛び込んで死んでしまうことである。

15.「夏の風は犬も食わぬ」というのはまったく馬鹿らしいことだと いうことである。このことわざは日本人の考え方と関係があった。 馬鹿は風引かぬという格言があった。このことわざは夏に風が 引いたら、馬鹿なことをしたとあらわしたことである。

16.「夏の虫水を笑う」というのは自分の狭い見聞だけで世間を判断 するたとえである。このことわざは秋にある読書週間と関係が あった。日本人は知識を増えるためにこの習慣を作って、この ようなことわざが生まれてきた。 
17.「春の晚飯後三里」というのは春の日が長いということである。 このことわざは春分の日と関係があった。春分の日は昼と夜の 時間が大体同じになる日である。春分の日の数日後には、昼の 時間が長くなった。

18.「一人娘と春の日はくれそうでくれぬ」というのは一人娘と春の 日のたとえていうものである。このことわざは春分の日と関係が あった。春分の日は昼と夜の時間が大体同じになる日である。 春分の日の数日後に、昼の時閒が夜の時間より長くなった。 日本人の考え方、「暮れる」と「くれる」を与えたものである。

19.「冬来たりなば春遠からじ」というのはつらく箃しい境遇を 堪え抜けば、必ず幸せな繁栄のときが来るというたとえである。 このことわざは、冬にある文化の冬至と立春と関係があった。冬 の辛さに与えれば暖かい春が待っていることを表している。

20.「物言えば唇寒し秋の風」というのは人の悪口を言うと、後で 自分自身愉快な思いをする。このことわざは日本人の考え方と 関係があった。このことわざは秋の風と同じようなことで、人の 悪口を言うと寒気が寄ってくる。

\section{D. 結論}

本研究の結論は以下のようである。

1. ことわざ辞典から季節を表すことわざは 20 つ発見された。

2. 発見された 20 つのことわざから 12 つのことわざが日本文化に 関係があった。

3. 季節を表すことわざは自然を表すだけでなく、とある出来事や 忠告などを表している。

4. ことわざは、自然あるいは季節に影響される文化が裏付けている。

\section{E. 参考文献}

Moleong, L.J. (2007) Metodologi Penelitian Kualitatif. Bandung : PT. Remaja Rosdakarya. 
Sudjianto. (2007) Bahasa Jepang dalam Konteks Sosial dan Kebudayaannya. Bandung: UPI PRESS diambil dari : http://file.upi.edu/Direktori/FPBS/JUR._PEND._BAHASA_JEPA NG/195906051985031-

SUDJIANTO/7._Buku_Sosiolinguistik.pdf. (diakses tanggal 14 September 2014).

Sugiyono. (2012) Metode Penelitian Kuantitatif Kualitatif dan R\&D. Bandung : Alfabeta.

Sulasman., \& Gumilar, S. (2013) Teori-teori Kebudayaan dari Teori hingga Aplikasi. Bandung : Pustaka Setia.

Sutedi, D. (2011b) Penelitian Pendidikan Bahasa Jepang. Bandung : Humaniora.

Tumanggor, R., dkk. (2014) Ilmu Sosial dan Budaya Dasar. Jakarta : Kencana. 